\title{
CONFLICTING TENDENCIES IN THE DEVELOPMENT OF SCIENTIFIC AND TECHNICAL LANGUAGE VARIETIES: METAPHORIZATION VS. STANDARDIZATION
}

\author{
LARISA ILLJINSKA \\ Riga Technical University \\ larisa.iljinska@rtu.lv \\ TATJANA SMIRNOVA \\ Riga Technical University \\ tatjana.smirnova@rtu.lv
}

\begin{abstract}
The present paper discusses relations between meaning and context as an interactive process that promotes cognition and communication, both intralingual and interlingual. The article also studies two evident conflicting tendencies in the development of technical language: metaphorization and standardization. Metaphorical meaning extension is characteristic of technical vocabulary in all discourse domains. At the same time, contemporary development of corpus linguistics facilitates standardization of terms. Taking into account pragmatic aspects of the text environment, i.e. referential, situational, cultural and social contexts, language users can interpret the meaning of new terms, establish relations and interconnections between terms and concepts within a text, domain and entire scientific and technical discourse. In the present article, observations on the nature and application of contemporary technical terminology are made on the basis of extensive empirical research.
\end{abstract}

Keywords: scientific and technical discourse, technical language, extension of meaning, metaphorization, standardization, pragmatic analysis

\section{Introduction}

The development of new technologies, a growing volume of information, and increase in international cooperation in the scientific, technological and industrial fields are among the factors, which determine the central role of technical language in contemporary information exchange.

Scientific and technical language is the most rapidly developing variety of language and the major source of new concepts. Contemporary scientific and technical language is characterized by the tendency for internationalization of vocabulary, borrowing of nonequivalent lexis, compounding, and extension of meaning of terms by means of metaphorization, thus following the development trends characteristic of general language. However, changes in the scientific and technical language are more dynamic, 
and therefore the process of creation of new lexical units is always one step ahead as compared to general language.

The dynamic changes in scientific and technical discourse determine contemporary processes the scientific and technical language undergoes, and call for new approaches to the analysis of texts within the discourse under discussion.

The changes in the nature of the technical text may be considered a reason for the development of the conflicting tendencies characteristic of the contemporary technical vocabulary. The main conflict is caused by the necessity to find balance between the process of formalization or standardization of technical vocabulary on the one hand, and the process of extension of meaning of terms by means of metaphorization on the other.

The present article aims at the analysis of the conflicting tendencies in the development of technical vocabulary, i.e. standardization and metaphorization. The article mainly studies coinage, application and translation of metaphoric terms in scientific and technical discourse. The complicated mechanisms underlying the processes of meaning formation and extension are illustrated in the article considering terms from the fields of ICT, Civil Engineering and Economics.

The challenges associated with decoding of meaning of metaphoric terms in context are most apparent when the message should not only be interpreted by the text recipient, but also re-encoded in another language. Therefore, technical translation is considered by the authors to be a promising tool for theoretical investigation because studying the processes of meaning creation and meaning transfer between the languages can promote understanding of the complicated processes occurring within the contemporary technical language. Hence, the relations between meaning and context as an interactive process that promotes cognition and communication, both intralingual and interlingual, are investigated in the present article. The meanings of metaphoric terms discussed in the article are contrasted in two languages, English and Russian.

\section{Scientific and Technical Discourse}

Scientific and technical discourse is defined in the paper as professional communication that covers different areas of science and technology. The discourse comprises texts belonging to many genres, for example, articles, reports, books, study books, manuals, technical specifications and codes.

According to Beaugrande (2001), a general dialectical model, in which language and discourse represent theory and practice respectively, can be used in investigating texts, and translated texts in particular. Language can be defined as a theory of human knowledge and experience, and discourse as its practice. Technical discourse as practice runs ahead of theory since its practical aspects are more accessible and operational, and the processes are more dynamic.

A text is defined as a communicative event that contributes to a discourse, which is a configuration of mutually relevant texts. Thus, scientific and technical discourse is a potentially endless chain of associations and correlations of texts within a particular field and texts of other fields of the discourse (cf. Beaugrande, 2001).

The technical or special text, as defined for the purposes of this article, comprises not only texts on technical subjects, but also texts in other specialized fields, written using 
Language for Special Purposes (LSP). In this respect, the authors share the opinion held by such scholars as Aixela (2004:29), Beaugrande (2001), and Cabre (1998:68).

Discussing the criteria for defining a 'special language', which in this article is referred to as technical language, Cabre adapts Halliday's approach to discourse as a combination of field, tenor and mode variables, and notes that special language pragmatically can be characterized by three variables: subject field, users who have respective subject knowledge, and situation in which communication takes place, i.e. in situations governed by scientific and technical criteria. (cf. Cabre 1998:65).

Each subject field is specific with relation to the set of concepts and terms it employs. Sager (1998:261) notes, "Terms [...] are endowed with a special form of reference, namely that they refer to discrete conceptual entities, properties, activities or relations which constitute the knowledge space of a particular subject field". The requirements put forward by each particular discipline determine the prevailing tendencies in terminology creation and development.

Thus, every subject field employs a separate special language, and the set of these special languages forms the entire specialized discourse. The heterogeneous nature of the scientific and technical discourse lies in the fact that it covers a wide range of subject fields.

\section{Technical Text}

Traditionally technical text was considered to be a relatively static area regulated by a set of norms and conventions. Glaser argues that it is characterized by "...clarity, precision and linguistic economy, as the key function of LSP (Language for Specific Purposes) is the specification, condensation and anonymity of the proposition (Glaser 1998:206 in Stolze 2009:125)". Technical text is still often associated with a precise, specific, and stylistically neutral mode of expression aimed at delivering accurate and unambiguous information to the reader, an extensive usage of terminology, absence of expressive vocabulary, and absence of cultural references (cf. Nord 1997).

But nowadays the nature of technical text has been changing, as the text is developing to meet the needs of the present time and globalized science, and, respectively, the nature of terms has been changing to account for the dynamics of the change of the text.

Traditional conventions of technical text production are not strictly observed. There is an apparent tendency for hybridization of technical text determined by blurring of both the boundaries between scientific and technical disciplines and between styles and genres. Moreover, hybridization of texts occurs also on the level of text function. It may be difficult to classify a text as belonging to one particular genre and performing one particular function.

Considering text typology with the reference to text function, Hatim and Mason argue:

"Many attempts have been made to set up a typology of texts [...] But all attempts are beset by the same problems. [...] we run the risk of ending up with virtually as many text types as there are texts. [...] multifunctionality is the rule rather than the exception." (Hatim and Mason 1990). 
Conventionally, text hybridity is mainly discussed in the context of translation activity. However, it should be realized that under the influence of globalization specific linguistic and cultural conventions of text production change or merge, and thus a hybrid text is produced not only in translation process, but also as an original text created in a specific cultural space, which is often in itself an intersection of different cultures (cf. Schaffner, Adab 2001).

Thus, it may be stated that contemporary technical text is often hybrid with respect to the field, genre, style, and function. The apparent tendency for hybridization is one of the main characteristic features of the changing nature of the technical text.

\section{Technical Vocabulary}

The tendencies in the development of technical text have caused changes in the development of technical vocabulary. Traditional characteristics of an ideal term imply that it is monosemic within a particular field, does not have synonyms, transparent, is free from connotations, and its meaning is unambiguous and not dependent on the context (cf. Wright, Budin 2001). However, contemporary terms do not always meet the traditional requirements put forward by conventional terminology schools often being polysemic, metaphoric, and context-dependent.

Terms are no longer seen as part of "semi-artificial language deliberately devoid of any of the functions of the lexical items" (Sager 1990:58). Sager argues that there is an increasing tendency to analyze terminology in its communicative and linguistic context. Temmerman and Kerremans in their turn point out that in contemporary terminology the principles of term monosemy and mononymy are questioned, "Also the univocity principle (only one term should be assigned to a concept and vice versa) has been questioned and relativised. It has been shown that understanding is a never-ending process in which synonymy and polysemy play a role." (Temmerman, Kerremans 2003:2).

Thus, in spite of the fact that technical terminology of different disciplines is generally field specific, many texts of the discourse under discussion are crossdisciplinary, multi-functional, less formal and all together hybrid. Hybridity of technical texts complicates the problem of polysemy and synonymy, because terms from different fields may be used simultaneously in one text. It is not always possible to identify the exact field the term belongs to and then to select a relevant field specific meaning in decoding and translation. Moreover, usage of expressive means and cultural references in the technical text often determine context-dependent character of some terms.

Modern terms, which generally do not meet the requirements set for ideal terms, potentially pose translation problems. These problems may be caused by various reasons, such as lack of referential equivalence, intradisciplinary polysemy, culture specific allusions embodied in the meaning of a term, and impossibility to transfer the metaphoric component of meaning of the term into the target language. One of the main apparent tendencies in the contemporary usage of terms is that their meaning is not only determined by the field, but is also dependent on the context. 


\section{Meaning and Context in Technical Text: Pragmatic Approach}

Relations between meaning and context are of particular importance as they represent an interactive process that enables cognition and productive communication.

Text as a complex multifunctional structure includes various types of context. In order to interpret the text both intralingually and interlingually the recipient should be aware of these contexts, some of which can be more important than others. The linguistic, situational, referential, epistemic, cultural, and social contexts are of particular importance in texts that perform more than one function.

The types of context that are of particular concern for participants in scientific and technical discourse are considered below.

Situational context is the extralinguistic or physical context. The notion of context of situation was introduced by Malinowski (1923), who considered that each text possesses this type of context. It spreads beyond the limits of a text or conversation. Situational context has many aspects such as time, place, environment, experience and other facts of reality in which the action takes place.

Referential context refers to the topic of a text. In technical text referential context is determined by the subject field.

Epistemic context is the background knowledge that text producers put into their message.

Cultural context comprises all aspects of life, traditions, customs, beliefs, values, and ideas shared by individuals of a particular group of people reflected in the respective language.

Social context reflects the relationships between the sender and addressee and is interpreted differently depending on their belonging to a certain social group. Social context is closely correlated to cultural context (cf. Malmkjaer 2002).

Context embraces the environment of text production, including the genre and the function of the text, as well as such extralinguistic factors as social and cultural settings. Stolze argues that "....any message within a technical or scientific discourse field includes both subject-relevant information and some implicit references to the cultural background of the person speaking."'(2009:124). Although social and cultural settings are frequently considered to be irrelevant in technical text, it has been pointed out that inability to account for these types of context may lead to misinterpretation of the implicature of the text (cf. Byrne 2010; Beaugrande 2001). The presence of social and cultural references in contemporary technical texts is an evidence of the changing nature of the text.

The pragmatic analysis of the interrelations between meaning and context in technical text is carried out considering metaphoric and context dependent terms in three subject fields of scientific and technical discourse.

\subsection{Information and Communication Technologies}

The first field under consideration is Information and Communication Technologies (ICT). It is the most rapidly developing field of the three, and it is the most technical one. Metaphoric extension of meaning in context as a pattern of term formation is widely 
used. For example, concepts of electricity and light, on the one hand, are purely technical; on the other hand, many terms associated with these concepts have been created by means of metaphoric meaning extension. Water imagery is used to describe the movement of light or radio waves and such terms as stream, waves, current, and their derivatives constitute an integral part of terminology in the field of ICT. Water imagery is extended further to denote new concepts, such as, for example, a new metaphor 'cloud', which is used to signify a virtual server in particular or the Internet in general:

(1) While you can offload some of your applications to the cloud, chances are there are still going to be some mission-critical applications that simply need to stay in-house ${ }^{1}$.

Considered outside the context, the sentence cannot be interpreted correctly, and given that the term cloud is relatively new, a recipient without sufficient background knowledge most likely would fail in interpreting the sentence.

(2) This type of communication can be performed with a null modem cable for full handshaking ${ }^{2}$.

In the example above, the metaphor handshaking used to denote the process of establishing a connection between two stations may also pose a potential intralingual and interlingual translation problem. The tenor of the metaphor, namely, connection, is not fully evident if the text users are not familiar with the process in question.

Another new metaphoric term is man-in-the-middle attack (MITM), which may also be referred to as bucket brigade attack and even Janus attack. According to the computer term glossary provided by Microsoft, it is a security attack in which an attacker intercepts and possibly modifies the data that is transmitted between two users (Online 1). On the one hand, the term meets the major requirement put forward to an ideal term, i.e. it is monosemic in the given field; on the other hand, there are synonymous terms frequently used, and none of them is stylistically neutral. An ability to derive the meaning of metaphoric terms from the context would determine success in interpreting the message.

Specialists who either work in the sphere or translate the texts in the field of ICT should have extensive background knowledge, as well as 'contextualized intuition' i.e. the ability to find the nearest common sense interpretation of the unknown element within the context (cf. Gerding-Salas 2000). They should be competent in application of complicated terms, occasionally denoting highly abstract concepts.

\subsection{Civil Engineering}

The next subject field has been chosen as the medium for analysis due to its explicitly cross-disciplinary nature, thus being a perfect medium for illustrating the main tendencies in the development of technical text and technical vocabulary.

1 „Cloud Computing. A Practical Approach” (2009). The McGraw-Hill Companies.

2 http://www.lammertbies.nl/comm/info/RS-232_flow_control.html [Accessed on 5 May, 2011] 
Complicated construction terms have been developed since ancient times in Babylon, Greece, and Rome, thus a vast body of terms have been formalized and standardized across many languages. However, with the development of building processes and practices, the field became more complicated. Different disciplines within the field of civil engineering employ methods, and, respectively, terminology of other fields. For example, resistance of materials has a direct relation to physics and chemistry. Contemporary building design is based on computer modeling (CAD), so the texts in the field may contain terminology associated with computer science; the calculation of energy efficiency of residential constructions involves an analysis of human bodily reactions to assess heat comfort, and thus makes references to medical terminology. Alike, texts on sustainable building practices and living buildings feature terminology from the fields of life sciences. Human strife for comfort, desire to organize sustainable living environment, environmental concerns associated with civil engineering, as well as change in aesthetic views and functional requirements set for residential and civil constructions have led to the change in life style and, moreover, in values people ascribe to civil engineering constructions. This, in its turn, has led to a change of vocabulary used in the field, to appearance of new concepts, and, respectively, new terms.

It should be noted that contemporary technical texts on civil engineering display a tendency for standardization of terminology of professional vocabulary. Extensive application of computer design software has led to formalization of terminology, development of product and activity nomenclatures, in order to ensure interoperability between various types of software. Although texts in the field do not always display consistency in using standardized terminology, and professional communication to a great extent relies on the usage of professionalisms, the tendency for cross-disciplinary unification of terminology is apparent. It may be concluded that the tendency for standardization of vocabulary is underway, along with the conflicting tendency for metaphorization.

Table 1 presents terms created by means of metaphoric meaning extension in English along with their definitions and translation into Russian.

\begin{tabular}{|l|l|l|}
\hline \multicolumn{1}{|c|}{ English } & \multicolumn{1}{|c|}{ Definition } & \multicolumn{1}{|c|}{ Russian } \\
\hline $\begin{array}{l}\text { Sandwich } \\
\text { construction }\end{array}$ & $\begin{array}{l}\text { Composite construction of alloys, } \\
\text { plastics, wood, or other materials } \\
\text { consisting of a foam or honeycomb } \\
\text { layer laminated and glued between } \\
\text { two hard outer sheets. }\end{array}$ & Многослойная конструкция \\
\hline $\begin{array}{l}\text { Honeycomb } \\
\text { brickwork }\end{array}$ & $\begin{array}{l}\text { a wall in which bricks are } \\
\text { deliberately spaced to allow for } \\
\text { ventilation or to achieve a visual } \\
\text { effect. }\end{array}$ & $\begin{array}{l}\text { Сквозная кирпичная стена } \\
\text { ширий в полкирпича }\end{array}$ \\
\hline $\begin{array}{l}\text { Butterfly } \\
\text { twisted } \\
\text { ties }\end{array}$ & $\begin{array}{l}\text { Butterfly shaped rigid, corrosion- } \\
\text { resistant metal ties fitted into the bed } \\
\text { joints across the cavity of a cavity } \\
\text { wall. }\end{array}$ & $\begin{array}{l}\text { Скрученные } \\
\text { связи, закрепы }\end{array}$ \\
\hline $\begin{array}{l}\text { Herringbone } \\
\text { strutting }\end{array}$ & $\begin{array}{l}\text { The type of cross bracing used } \\
\text { between floor joists to increase }\end{array}$ & $\begin{array}{l}\text { Косые балкам распорки (между } \\
\text { балкамерекрытия) }\end{array}$ \\
\hline
\end{tabular}




\begin{tabular}{|l|l|l|}
\hline \multicolumn{1}{|c|}{ English } & \multicolumn{1}{|c|}{ Definition } & \multicolumn{1}{|c|}{ Russian } \\
\hline $\begin{array}{l}\text { Tongue and } \\
\text { groove }\end{array}$ & $\begin{array}{l}\text { Tongue and groove refers to strip or } \\
\text { plank flooring where each plank has a } \\
\text { "tongue" or convex side and a } \\
\text { "groove" or concave side on the } \\
\text { opposite edge. }\end{array}$ & $\begin{array}{l}\text { Шпунтовое } \\
\text { соединение шпунт-паз }\end{array}$ \\
\hline $\begin{array}{l}\text { Dogleg stair } \\
\text { configuration }\end{array}$ & $\begin{array}{l}\text { a staircase which has no well and a } \\
\text { bend of 180 in it, usually at a } \\
\text { landing halfway between floors. }\end{array}$ & $\begin{array}{l}\text { Полуоборотная } \\
\text { двухмаршевая лестница c } \\
\text { промежуточной площадкой }\end{array}$ \\
\hline $\begin{array}{l}\text { Eye-lid } \\
\text { window }\end{array}$ & $\begin{array}{l}\text { The curved top and the half round } \\
\text { fixed-sash window. }\end{array}$ & $\begin{array}{l}\text { Полукруглое секционоее } \\
\text { окно }\end{array}$ \\
\hline
\end{tabular}

Table 1: Metaphoric Terms in the Field of Civil Engineering

Potential translation problems associated with rendition of terms formed as a result of metaphoric meaning extension vary depending on the degree of interlingual translatability. It may be noticed that metaphoric representation is not sustained in translation of any of the listed terms. In all cases denotational meaning is given priority, and the metaphoric meaning is lost. In general, most apparently the problem of loss of essential components of meaning arises in translation of terms formed as a result of metaphoric meaning extension. Having analyzed the terms in Table 1, it may be noticed that in Russian terms formed by metaphoric meaning extension are not as common in the field of civil engineering as in English. The frequency of application of metaphoric terms in two working languages is worth further investigation.

Another potential problem is ambiguity caused by various reasons, such as polysemy of terms and their dependence on the context. The text user, translator in particular, has to look for contextual clues in order to understand the meaning of the text. The following example illustrates the problem of this kind.

(3) Green roof. The buildings are intentionally concealed from the parking lot by a green roof. (...) On the other side, a gabion retaining wall holds back the soil that forms the green roof seen from the parking lot. ${ }^{3}$

The contextual clues that allow deciphering the exact meaning of a term are presented further in the text and due to such disposition may remain unnoticed. Outside context green roof can be interpreted in at least three different ways: the roof colored green, the roof, which has been constructed using environmentally friendly technologies, and the roof, which is covered with soil and greenery. In the given example, the recipient may understand that the term in question is used in the latter meaning only having read the next paragraph, that is, outside immediate context. The clue that may help make this conclusion is information that the roof is formed from soil.

Multi-disciplinary character of the field of civil engineering manifests itself in its close connection with the field of architecture, which lies at the crossroads of art and

\footnotetext{
${ }^{3}$ Rael, Ronald (2008). Earth Architecture, Princeton Architectural Press
} 
technology. The images of architecture are visible and expressive, these images can be perceived differently depending on national, historical and individual aesthetic values. The texts in architecture cover both craft and art, and their interpretation requires more than just general background knowledge in the subject field. Informative technical texts on architecture often contain expressive means of language, performing a secondary expressive function. Thus, many of them are multi-functional.

Both a text user and a translator should possess the necessary expertise not only to understand the meaning of complicated terms, but also to decode historical and cultural implications communicated by these terms. For example, the term naos means sanctuary, but in each culture there is a separate term for sanctuary.

\begin{tabular}{|c|c|c|}
\hline Term & Definition & Translation \\
\hline Delubrum & $\begin{array}{l}\text { (in ancient Rome) a temple, shrine, or } \\
\text { sanctuary }\end{array}$ & Храм, святилище \\
\hline Garbhagriha & $\begin{array}{l}\text { Small unlit shrine of a Hindu temple. } \\
\text { Garbhagriha or garbha griha is a Sanskrit } \\
\text { word meaning the interior of the sanctum } \\
\text { sanctorum, the innermost sanctum of a } \\
\text { Hindu temple. }\end{array}$ & Святилище, гарбхагриха \\
\hline Gurdwara & a Sikh temple in India & $\begin{array}{l}\text { Сикхский } \\
\text { святилище, гурудвара }\end{array}$ \\
\hline Naos & $\begin{array}{l}\text { an ancient temple; the enclosed part of such } \\
\text { a temple; cella }\end{array}$ & Храм, святилище, наос \\
\hline Sacellum & $\begin{array}{l}\text { In the Roman period, a small sacred } \\
\text { enclosure, it contained an altar and } \\
\text { sometimes also a statue of the god to whom } \\
\text { it was consecrated. }\end{array}$ & $\begin{array}{l}\text { Святилище } \\
\text { открытым } \\
\text { сакеллум }\end{array}$ \\
\hline Sacrarium & $\begin{array}{l}\text { Ecclesiastical (of or associated with the } \\
\text { Christian Church) - the sanctuary or chancel; } \\
\text { The sanctuary or sacristy of a church. }\end{array}$ & $\begin{array}{l}\text { Святилище, ризница, } \\
\text { дарохранительница }\end{array}$ \\
\hline Shrine & $\begin{array}{l}\text { a place of worship hallowed by association } \\
\text { with some sacred thing or person; enclose in } \\
\text { a shrine, as of an object for religious } \\
\text { purposes }\end{array}$ & Святилище, рака \\
\hline Tabernacle & $\begin{array}{l}\text { a Jewish place of worship; in Judaism - the } \\
\text { Biblical tabernacle or the Temple in } \\
\text { Jerusalem }\end{array}$ & $\begin{array}{l}\text { Храм, } \\
\text { дарохранительница, } \\
\text { табернакль }\end{array}$ \\
\hline
\end{tabular}

Table 2: Culture Specific Terms for the Notion SANCTUARY

Table 2 features a list of terms that in certain contexts can be translated into Russian as святилище, that is, sanctuary. The table comprises the terms associated with Indian, Roman, Greek, and Jewish architecture. Translating such culture and history specific lexis, the translator constantly has to make a choice: to translate the term or to use a borrowing in order to preserve historical, cultural or religious coloring of the source text. Borrowed variants of terms, presented in italic, demonstrate that such variants are 
registered in the dictionaries. It is interesting to note that 5 out of 8 terms can be translated using transcription, however, only one of the terms, namely, naos - Haoc, has fully assimilated in Russian.

The problem is complicated by the fact that both in English, Russian and many other languages the term sanctuary or its equivalent is polysemic in the field of religious architecture, it may be used to refer both to a sacred place, such as a church, temple, or mosque, and the holiest part of a sacred place (www.thefreedictionary.com). Thus, translators have to make decisions not only on the choice between a borrowed or culturally neutral word, but also on the exact meaning of the original term in context.

Background knowledge is an integral aspect of recipient's competence that may facilitate accurate interpretation and rendition of the historical, cultural and national references present in such texts.

\subsection{Economics}

Economics is by far the least technical of all three disciplines discussed in the article. It may be argued that economics is not a technical, but rather a social discipline; however, within the framework of the present article, considering the definition of the technical text as of any text employing LSP within professional discourse provided above, it is treated as a technical field with developed terminology.

The focus on various aspects of human conduct such as decision making, motivation, and behavioral patterns makes texts on economics, especially texts on marketing and management, highly dependent on cultural, historical and social contexts.

In general, texts on economics display inconsistency in usage of terminology and are rich in professionalisms, jargonisms and ad hoc terminology. Such fields as marketing, stock market, retailing and management employ terms created as a result of meaning extension increasingly frequently. Translation of such terms requires application of all integral aspects of a translator's background knowledge, especially keeping in mind that translation of terminology and professionalisms is not the only issue. Words belonging to general language may fulfill the function of terms, and as such should be carefully treated in translation. Dominguez and Rokowski (2002) note on translation of texts in the field of banking and finance, another domain conventionally belonging to the field of economics, “... when words belonging to the so-called General English next to specific terms and within a specific context, they contain nuances that must be accounted for in the final translation".

Table 3 lists 10 metaphoric terms used in the field of Economics. The definitions are provided with the reference to the web-site investopedia.com.

\begin{tabular}{|l|l|l|l|}
\hline Nr. & Term & \multicolumn{1}{|c|}{ Definition } & \multicolumn{1}{|c|}{ Translation } \\
\hline Group 1 & $\begin{array}{l}\text { Killer } \\
\text { bee }\end{array}$ & $\begin{array}{l}\text { Those who help a company fend off a } \\
\text { takeover attempt with the use of defensive } \\
\text { strategies. }\end{array}$ & $\begin{array}{l}\text { Инвестиционный банк, } \\
\text { защищающий } \\
\text { компанию от попыток } \\
\text { её поглощения }\end{array}$ \\
\hline
\end{tabular}




\begin{tabular}{|c|c|c|c|}
\hline Nr. & Term & Definition & Translation \\
\hline 2. & $\begin{array}{l}\text { Loan } \\
\text { shark }\end{array}$ & $\begin{array}{l}\text { A person or entity that charges } \\
\text { borrowers interest above an established } \\
\text { legal rate. }\end{array}$ & Ростовщик \\
\hline 3. & Bull & $\begin{array}{l}\text { An investor who thinks the market, a } \\
\text { specific security or an industry will rise }\end{array}$ & $\begin{array}{l}\text { Спекулянт, играющий } \\
\text { на повышение курса } \\
\text { акций }\end{array}$ \\
\hline 4. & Bear & $\begin{array}{l}\text { An investor who believes that a particular } \\
\text { security or market is headed } \\
\text { downward. Bears attempt to profit from a } \\
\text { decline in prices. }\end{array}$ & $\begin{array}{l}\text { Спекулянт, играющий } \\
\text { на понижение курса } \\
\text { акций }\end{array}$ \\
\hline \multicolumn{4}{|c|}{ Group 2} \\
\hline 5. & $\begin{array}{l}\text { Blue } \\
\text { Skies } \\
\text { Laws }\end{array}$ & $\begin{array}{l}\text { State regulations designed to protect } \\
\text { investors against securities fraud by } \\
\text { requiring sellers of new issues to register } \\
\text { their offerings and provide financial details. }\end{array}$ & No \\
\hline 6. & $\begin{array}{l}\text { Green } \\
\text { shoe }\end{array}$ & $\begin{array}{l}\text { When a company goes public it may grant } \\
\text { its underwriting firm an option an extra } \\
\text { numbers of shares. This prevents the } \\
\text { underwriter from making a loss if the issue } \\
\text { is under subscribed and the underwriter } \\
\text { having to buy shares on the open market to } \\
\text { cover a short position. }\end{array}$ & $\begin{array}{l}\text { Соглашение о праве } \\
\text { купить } \\
\text { дополнительные акции } \\
\text { по первоначальной } \\
\text { цене }\end{array}$ \\
\hline 7. & $\begin{array}{l}\text { Grey } \\
\text { knight }\end{array}$ & $\begin{array}{l}\text { In a take-over situation, a third party, acting } \\
\text { as a counter bidder, whose intentions } \\
\text { towards the target company are not at all } \\
\text { clear. Grey knights are normally unwelcome } \\
\text { to both the target and the original raider. }\end{array}$ & Серый рыцарь \\
\hline 8. & $\begin{array}{l}\text { White } \\
\text { knight }\end{array}$ & $\begin{array}{l}\text { A company that makes a friendly takeover } \\
\text { offer to a target company that is being faced } \\
\text { with a hostile takeover from a separate } \\
\text { party. }\end{array}$ & Белый рыцарь \\
\hline \multicolumn{4}{|c|}{ Group 3} \\
\hline 9. & $\begin{array}{l}\text { Fallen } \\
\text { angel }\end{array}$ & $\begin{array}{l}\text { Colloquial term for a company, or shares in } \\
\text { a company, whose rating has recently fallen } \\
\text { significantly. }\end{array}$ & $\begin{array}{l}\text { Высокодоходная } \\
\text { облигация, потерявшая } \\
\text { уровень, приемлемый } \\
\text { для инвесторов }\end{array}$ \\
\hline 10. & $\begin{array}{l}\text { Baby } \\
\text { Bills }\end{array}$ & $\begin{array}{l}\text { A nickname given to the hypothetical } \\
\text { companies that would have formed if the } \\
\text { Justice Department had broken up Microsoft } \\
\text { Corporation. }\end{array}$ & No \\
\hline
\end{tabular}

Table 3: Metaphoric Terms in the Field of Economics 
The terms in table 3 can conditionally be divided into three groups - animal metaphors, color metaphors and metaphors based on allusions to culture specific and situational knowledge.

The terms presented in the table exemplify several tendencies in creation of terms by means of metaphoric meaning extension, namely:

1. terms may be created on the basis of various field of reference (color symbolism, animal symbolism, etc);

2. terms may be connotationally loaded (killer bee, loan shark);

3. terms may be created on the basis of allusions to cultural knowledge (fallen angel);

4. terms may be created on the basis of allusions to situational context (baby Bills). Terms from group 1, namely, killer bee and loan shark have been derived by means of metaphoric meaning extension using implied properties of respective animals as the tenor. Both terms are explicitly evaluative, both meanings imply certain connotations. In case with killer bee it is positive - the one who protects, in case with loan shark it is negative-merciless predator. Thus, neither meets all the requirements set for an ideal term. It may be argued that the lexical items are professionalisms rather than terms, however both entries are present in major business dictionaries (e.g. Merriam-Webster).

The terms bull and bear are well established in the English language. It may be argued that it is already the case of recognized polysemy of lexical items in question. Existence of derivatives acknowledges to this fact (e.g. bullish or bearish market). The tenor is not as evident as in case with other two terms belonging to the same group.

Only one term in the given group, loan shark, has an established equivalent in Russian, other terms are translated by means of explanatory translation. However, recently the terms bulls and bears have been frequently translated literally, as бык $u$ and медведи respectively. The application of these translation variants has very limited scope; they are used only in the professional environment of stock exchange. In such form the terms can hardly be considered metaphors, rather it is an interesting case of borrowed polysemy. It is worth noting that the Russian equivalent of loan shark, the term ростовщик, also bears explicitly negative connotation. Yet it may be notices that connotationally loaded terms are far less common in Russian than in English.

Group 2 comprises terms containing color reference. However, the extension of meaning underlying creation of these terms has occurred along different lines. The vehicle of the term Blue skies laws is a metaphor itself. Thus the term is an extended metaphor. The tenor of blue skies is security and safety. The term illustrates that the process of metaphorization can occur in several stages, potentially endlessly extending the meaning of a lexical item.

The term green shoe (greenshoe) has appeared as a result of meaning extension based on the principle of metonymy, as the term is an eponym. Eponymy is a subclass of metonymy (Lipka 2003). The term originated from the name of the company that first implemented the green shoe clause into their underwriting agreement - the Green Shoe Manufacturing Company (investopedia.com).

The terms grey knight and white knight employ colour symbolism as the basis of nomination. Although the term black knight is not included into the database used as the major source of reference in this article, namely investopedia.com, it is featured in other business English resources, e.g. businessdictionary.com. Apparently, terms have been 
created by analogy. White knight is the party that acts with good intent, black knight is the party acting in a hostile manner, and grey knight is the party intentions of which are not clear. White communicates the meaning of something positive, black symbolizes something negative, and grey is generally associated with obscurity.

It should be noted that color symbolism of the terms is to a great extent culture specific. The properties associated with white, black and grey referred to by the terms are conventionally ascribed to the colors in question in contemporary Western civilization. In Russian these colors bear the same symbolic or metaphoric meaning, so the terms are translated using calques, that is, translated literally. In order to interpret the terms correctly in the field of economics both itralingually and interlingually the recipient should be aware of both referential and cultural context.

Items belonging to group 3 can be interpreted within or across the languages only if the recipient possesses certain cultural and epistemic knowledge. The metaphoric meaning of fallen angel is based on the reference to the Bible. The meaning of Baby Bills, which is an ad hoc professionalism, can be interpreted only if the user is aware of the issues concerning existence and development projects of the company Microsoft. It may be argued that the term will go out of use as soon as these issues are no more topical.

All terms in Table 3 clearly illustrate the tendency for metaphorization of business vocabulary. The awareness of referential, cultural and epistemic contexts of application of such terms is a prerequisite for understanding of the proposition of the message.

The role of background knowledge is seminal in interpretation of texts in the field of economics due to several reasons. One of the reasons is that the texts are often hybrid, cross-disciplinary and multi-functional. The tendencies, characteristic of the development of technical language, are most explicitly reflected in the texts on economics.

\section{Standardization vs. Metaphorization}

The main conflict a contemporary terminology expert faces is a difficulty in establishing balance between the process of formalization or standardization of technical vocabulary initiated by the development of corpus linguistics, compilation of multi-lingual terminological data bases, as well as digital processing of texts, and the on-going process of extension of meaning of terms by means of metaphorization in the scientific and technical discourse.

Many scholars (e.g. Temmerman 2000, Cabre 1998, Sager 1990) argue about changes in the nature of terms, acknowledging that terms acquire new characteristic features. Sager's modern terminological theory adopts a corpus-based approach to lexical data collection in order to make sound conclusions on application of terms in context, i.e. frequency of use, usage in literal or transferred meaning, etc.

The need for standardization of terms is determined by the fact that there is no always one-to-one relationship between a concept and a term denoting it in a language. One and the same concept may be denoted by several terms, and one and the same term may denote a range of concepts. Thus, the users of terms have to face the problem of term synonymy and term polysemy respectively. It is important to note that the process 
of extension of meaning by metaphorization is one of the reasons for appearance of polysemic terms. The need for intradisciplinary agreement on the application of terms and the need for establishing to the extent possible one-to-one correspondence between the terms in two or more languages have promoted both intralingual and interlingual processes of term standardization.

Intradisciplinary agreement on the usage of terms facilitates communication among specialists within a given field, promotes understanding devoid of possibility for misinterpretation, and exchange of information. In the process of standardization concepts are ascribed appropriate denominators. Standardization is associated with selecting a preferred term among alternatives, usually synonyms. Terms are better recognized both within and outside context. Standardized terminology is further used to represent the basis of knowledge which is shared by members of professional community.

According to Sager, standardization of terminology can work in two directions prospectively and retrospectively. However, nowadays still most terms are standardized retrospectively, that is, a preferred term is selected either among alternative variants already in use, or is coined to substitute an existent variant that is ambiguous and imprecise.

Retrospective standardization is reactive, it cannot account for all changes that occur within a professional discourse. New ideas and respectively concepts may be developed in more than one discipline at once. It leads to 'parallel designation' for the same phenomenon or concept (cf. Sager 1998:256).

Sager $(2001: 258)$ points out:

"Standardized terms are widely used in cases where the differences among language users are minimal in terms of situational, social and intellectual roles, for example in discourse among specialists. The greater the differences between speakers the greater the need to use a higher proportion of definitions, paraphrases and circumlocutions rather than standardized terms. Standardization can only be applied to codified knowledge."

Synonymy, polysemy and pragmatic variation of meaning of words in context, which are considered problems in terminology management and standardization, are becoming natural phenomena of scientific and technical language. Although standardization of terms in scientific and technical discourse remains an extremely useful tool that organizes knowledge, registers new terms, and helps optimize professional communication, creation and use of synonymous, polysemic, and metaphoric terms is a process, which can hardly be restricted by standardization.

The following case study illustrates the challenges associated with intralingual and interlingual standardization of terms created by means of metaphoric meaning extension.

\subsection{Case Study}

Metaphoric meaning extension is characteristic of scientific technical vocabulary in all discourse domains. Extension of meaning of one particular lexical item is one of the mechanisms of filling in lexical gaps in a language. A metaphoric transfer of meaning is inherent in human cognitive activity (cf. Carston 2010:297). Thus, following the recent 
findings of cognitive linguistics, metaphor can be defined as an essential conceptual tool based on the principle of analogy.

If a certain complex concept lacks a name, language users tend to extend the field of reference of an existing lexical item to denote this new concept, especially if it should be referred to on a regular basis. Complicated description used to denote the new concept in question may hinder communication. Baker (2011:18) with the reference to Bolinger and Sears (1968) notes that languages automatically develop very concise forms for referring to complex concepts if the concepts become important enough to be often talked about. A single morpheme can express a more complex set of meanings than the whole sentence. Such semantically complex words are extremely difficult to translate, in case there is no equivalent for them in the target language. Such words, often created by means of metaphoric meaning transfer, can be rendered only using descriptive translation to ensure comprehension. However, if the notion has to be referred to frequently within a certain field or in a particular target text, the problem of lack of precise label arises also in the target language.

One of the items that demonstrates extreme semantic complexity is the term leapfrogging. This complexity is aggravated by the fact that the term is polysemic not only across different fields, but also within a particular discipline. The term is used in such diverse disciplines as geology, telecommunications, electricity supply, logistics, business and military.

In the following case study the meaning of a term is analyzed within three fields considered in the present paper, namely, telecommunications, civil engineering, urban planning in particular, and economics, in which the term appears to be polysemic, and in the field of technology.

\begin{tabular}{|c|c|c|}
\hline Field & Definition & Translation \\
\hline Telecommunications & $\begin{array}{l}\text { Intermittent switching of delay (to } \\
\text { eliminate pulse pile-up) }\end{array}$ & 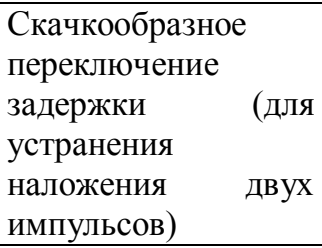 \\
\hline Technology & $\begin{array}{l}\text { Technology leapfrogging is 'bypassing } \\
\text { some of the processes of accumulation } \\
\text { of human capabilities and fixed } \\
\text { investment in order to narrow down the } \\
\text { gaps in productivity and output that } \\
\text { separate industrialized and developing } \\
\text { countries' }\end{array}$ & No \\
\hline Urban Planning & $\begin{array}{l}\text { The relationship, or lack thereof, } \\
\text { between subdivisions into zones. Such } \\
\text { developments are typically separated by } \\
\text { large green belts, i.e. tracts of } \\
\text { undeveloped land, resulting in an } \\
\text { average density far lower even than the } \\
\text { low density zones. }\end{array}$ & $\begin{array}{l}\text { Застройка } \\
\text { территории, на } \\
\text { которой осваивают } \\
\text { наиболее дешёвые } \\
\text { земельные участки }\end{array}$ \\
\hline
\end{tabular}




\begin{tabular}{|l|l|l|}
\hline Field & \multicolumn{1}{|c|}{ Definition } & Translation \\
\hline Economics 1 & $\begin{array}{l}\text { A theory of development which may } \\
\text { accelerate development by skipping } \\
\text { inferior, less efficient, more expensive } \\
\text { or more polluting technologies and } \\
\text { industries and move directly to more } \\
\text { advanced ones. Through leapfrogging } \\
\text { developing countries can avoid } \\
\text { environmentally harmful stages of } \\
\text { development and not need to follow } \\
\text { the polluting development trajectory of } \\
\text { industrialized countries }\end{array}$ \\
\hline Economics 2 & $\begin{array}{l}\text { Automatic increase (or claims for No } \\
\text { increase) in pay for a group of } \\
\text { employees on the grounds of } \\
\text { maintaining pay parity or differential } \\
\text { with another group of employees who } \\
\text { have won a pay increase }\end{array}$ & \\
\hline
\end{tabular}

Table 4: Field-Specific Meaning of the Term Leapfrogging

Analyzing the term leapfrogging, it may be noticed that in all fields under discussion the key sememe that provides ground for metaphoric meaning extension is movement/transition to a new position. The sememe sudden/abrupt movement skipping the next position is present only in terms in Economics 1 and Technology. It may be argued that the meaning of the term in Technology has been created by analogy with the term in Economics 1. Virtually, these two terms are closest in reference to the literal meaning of leapfrogging. It is interesting to note that exactly these meanings of the term are relatively standardized, whereas meanings in Telecommunications, Urban Planning and Economics 2 are not yet fully established, and thus are not registered in the majority of dictionaries. So these items can be considered rather professionalisms than accepted terms.

In two fields in question, namely, civil engineering and economics, as well as in the field of technology in general, the semantic scope covered by terms is extensive, and thus definitions are relatively long. If there is no corresponding term in the target language, a translator may employ three methods: to borrow a source term, to translate a metaphor, or to provide an explanation of a term in the target language to ensure comprehension. The term in question cannot be borrowed, as transcription of the term does not comply with phonetic and morphological rules of the Russian language. Translation by definition will pose a problem of lack of linguistic economy, as definitions are long, and if used often, will make the target text considerably longer than the source text. Translation of the term by its literal equivalent "чехарда" - а game in which one player kneels or bends over while the next in line leaps over him or her - may block comprehension, as, if used in the given contexts, the term would appear ambiguous and not transparent. Moreover, it should be taken into consideration that the established metaphoric meaning of the item in Russian has a negative connotation. 
Yexapda is used to refer to an uncontrolled process that may have unexpected consequences. That is another factor why rendition of the term in question by a corresponding target language metaphor does not appear to be a sound translation decision.

In Russian, only two meanings of the term have their translation equivalents - in Telecommunications and Urban Planning. Still, these equivalents are represented not by a single term, but rather by a definition.

The complex nature of the original concept has become more complicated in the process of meaning extension. Derived concepts cover even wider semantic scope, and thus a vast body of information is compressed within corresponding terms.

\section{Conclusions}

The nature of technical text has been changing, it is becoming more hybrid, crossdisciplinary, multi-functional and less formal. The tendencies in the development of technical text have determined changes in the nature of contemporary terms, which are often polysemic, metaphoric, and context-dependent. Synonymy, polysemy and pragmatic variation of meaning of terms in context are becoming natural phenomena of technical language.

These changes give rise to conflicting tendencies in the development of the contemporary technical vocabulary. The main conflict is caused by lack of agreement between the process of formalization of technical vocabulary initiated by compilation of technical text corpora and development of multi-lingual terminological data bases, and the on-going process of extension of meaning of the existing and newly created terms by means of metaphorization.

Standardization of terms in scientific and technical discourse is an important tool that helps establish intradisciplinary agreement on the application of terms and interlingual correspondence between the terms in two or more languages thus facilitating professional communication and exchange of information. However, processes of coinage and application of synonymous, polysemic, and metaphoric terms cannot be fully restricted and even accounted for by standardization.

The empirical study conducted in the paper demonstrates that at present users of technical texts should rely upon corresponding background knowledge which includes not only linguistic competence and the knowledge of a special subject field, but also awareness of situational, epistemic, cultural, and social contexts, or, in other words, understanding of the pragmatic aspects of the contemporary technical text.

Language for science and technology is a constantly growing flexible area with an immediate response to a developing situation, i.e. the language of primary term formation. The content and structure of technical text are continuously in a process of change and reorganization. One should realize that language is never complete and fixed, codified and standardized. 


\section{References}

Aixela, Franco (2004). The Study of Technical and Scientific Translation: An Examination of Its Historical Development. The Journal of Specialized Translation (29-47), 01.

Baker, Mona (2011). In Other Words. GB: Routledge.

Beaugrande de, Robert (2001). "Theory and Practice of Translation in the Age of Hypertechnology". Paper at the Second International Congress of Translators, Universidade Federal de Minas Gerais.

Byrne, Jody (2010). Technical Translation: Usability Strategies for Translating Technical Documentation. Netherlands: Springer.

Cabre, Teresa (1998). Terminology. Theory, methods and applications. Amsterdam/Philadelphia: John Benjamins Pub Co.

Carston, Robyn (2010). Metaphor: ad hoc concepts, literal meaning and mental images. In Proceedings of the Aristotelian Society 110 (3) (297-323).

Doninguez, Guadalupe \& Rokowski, Patricia (2002). "Implications in Transalting Economic Texts". Translation Journal 6, n.3.

Gerding-Salas, Constanza. (2000) "Teaching translation: problems and solutions" Translation Journal 4, n.3. (1-11).

Hatim, Basil \& Mason, Ian. (1990) Discourse and the Translator, London: Longman.

Lipka, Leonhard (2003). "Observational Linguistics and semiotics". In J. Hladk (ed.), Language and Function. To the memory of Jan Firbas. Amsterdam-Philadelphia: Benjamins.

Malinowski, Bronislaw (1923). „The Problem of Meaning in Primitive Languages” supplement to C.K. Ogden and I.A. Richards (eds.) The Meaning of Meaning (296336). New York: Harcourt Brace and World.

Malmkjaer, Kirsten (Ed.) (2002). The Linguistics Encyclopedia. GB: Routledge.

Nord, Christiane (1997). Translating as a Purposeful Activity: Functionalist Approaches Explained. Manchester: St. Jerome.

Sager. Juan (1990). A Practical Course in Terminology Processing. Amserdam/Philadelphia: John Benjamins Pub Co.

Sager, Juan (1998). "Terminology: standardization" \& "Terminology: theory". In Mona Baker (Ed.) Routledge Encyclopedia of Translation Studies. GB: Routledge

Shaffner, Christina \& Adab, Beverly. (2001) “The Hybrid Text in Translation”, In Across Languages and Cultures, 2 (2). Budapest, Acadmiai Kiad.

Stolze, Radegundis (2009). Dealing with cultural elements in technical texts for translation. The Journal of Specialized Translation, 11.

Temmerman, Rita \& Kerremans, Koen (2003). Termontography: Ontology Building and the Sociocognitive Approach to Terminology Description". In: Hajicov, E., Koteovcov, A., Mrovsk, J. (eds.), Proceedings of CIL17, Matfyzpress, MFF UK (CD-ROM). Prague, Czech Republic.

Wright, Sue Ellen \& Budin Gerhard (comps.) (2001). Handbook of Terminology Management: Volume 2: Application-Oriented Terminology Managemen. Amserdam/Philadelphia: John Benjamins Pub Co. 


\title{
Internet resources
}

Online 1 http://msdn.microsoft.com/en-us/library/cc246926\%28PROT.13\%29.aspx [Accessed on 10 June, 2011]

Online 2 http://www.lammertbies.nl/comm/info/RS-232_flow_control.html [Accessed on 5 May, 2011]

\section{Dictionaries and data bases:}

1. www.thefreedictionary.com

2. www.investopedia.com

3. www.ictregulationtoolkit.org

4. www.wikipedia.org

5. www.businessdictionary.com

6. www.multitran.ru

7. www.merriam-webster.com

8. http://www.websters-online-dictionary.org

9. www.definitions.net

10. www.macmillandictionary.com

\begin{abstract}
About the authors
Larisa Iljinska is a professor of philology; she has been Head of the Institute of Applied Linguistics of Riga Technical University (RTU) since 1999. Her research interests lie in semantics, pragmatics, discourse analysis, and translation of scientific and technical texts. She has authored over fifty publications, including four resource books for students majoring in various scientific and technical domains.
\end{abstract}

Tatjana Smirnova is an assistant professor specialising in linguistics and translation at the Institute of Applied Linguistics at Riga Technical University (RTU). Her research interests lie in language iconicity, semantics, pragmatics, and terminology. She conducts study courses in the theory of translation, consecutive translation, and target reading in special technical fields. 